DOI: https://doi.org/10.31933/jimt.v2i2

Received: 10 November 2020, Revised: 25 November 2020, Publish: 17 Desember 2020

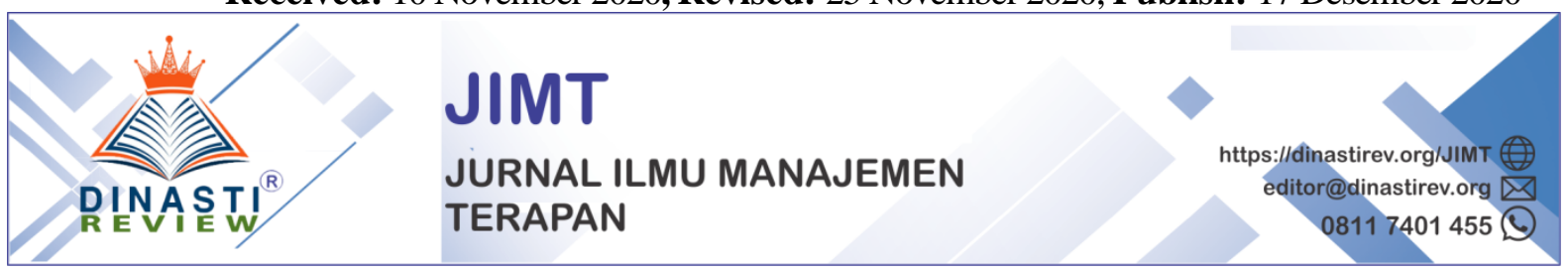

\title{
ANALISIS KINERJA KEUANGAN PT. BUKIT ASAM, Tbk DILIHAT DARI RASIO SOLVABILITAS, AKTIVITAS DAN PROFITABILITAS PERIODE TAHUN 2014-2019
}

\author{
Mastari \\ Universitas Mercu Buana, Jakarta, Indonesia, mastari865@gmail.com

\section{Corresponding Author: First Author}

\begin{abstract}
Abstrak: Laporan keuangan PT. Bukit Asam tersusun dalam bentuk laporan neraca dan laporan laba rugi yang diambil pada tahun 2014 sampai dengan tahun 2019. Tujuan melakukan analisis laporan keuangan untuk mengetahui keadaan keuangan perusahaan dari sisi nilai rasio keuangan. Penelitian ini untuk mengetahui kinerja keuangan PT. Bukit Asam, Tbk dilihat dari rasio profitabilitas, solvabilitas dan rasio aktivitas berdasarkan laporan keuangan perusahaan. Metode penelitian yang digunakan adalah analisis deskriptif menggunakan pengukuran rasio profitabilitas, solvabilitas dan rasio aktivitas. Sumber data dan informasi penelitian diperoleh dari Bursa Efek Indonesia. Dari hasil perhitungan rasio profitabilitas, solvabilitas dan rasio aktivitas rata-rata mengalami kenaikan serta penurunan yang fluktuatif dan tidak signifikan ditengah masih melamabatnya pertumbuhan ekonomi Indonesia pada 2014-2019. hal ini menunjukkan bahwa kondisi perusahaan dalam keadaan baik serta perlu melakukan beberapa langkah dalam mengatasi dampak dari melambatnya pertumbuhan ekonomi Indonesia dalam lima tahun terakhir.
\end{abstract}

Kata kunci : Kinerja Keuangan Rasio Profitabilitas, Solvabilitas dan Likuiditas

\section{PENDAHULUAN}

Laporan keuangan dalam perusahaan merupakan kewajiban yang harus dilakukan oleh perusahaan dalam melaporkan kinerja perusahaan, hal ini memiliki peran penting yang akan berimbas pada meningkatnya kinerja keuangan secara otomatis sumber dari daya yang dimiliki perusahaan. Selain itu laporan keuangan juga akan menjadi tolak ukur peningkatan kinerja perushaan dimata para investor dan pemegang saham. Laporan keuangan dapat memberikan arahan bagi perusahaan dalam mengatasi masalah setelah mengetahui kelemahan-kelemahan yang dimiliki perusahaan dan memperbaiki kelemahankelemahan tersebut. Persaingan dalam era pasar bebas di dunia usaha terutama dalam sektor pertambangan, membuat setiap pelaku bisnis dalam hal ini perusahaan harus semakin cermat menyikapinya dengan pesaing. Perusahan sektor pertambangan terus 
bertambah baik perusahaan tambang milik negara maupun perusahaan milik swasta ataupun milik asing. Salah satu perusahaan tambang milik pemerintah diantaranya PT.Bukit Asam, Tbk. Ditengah persangaingan industri pertambangan yang semakain ketat faktor lain yang menjadi tantangan perusahaan untuk tetap memperoleh keuntungan bagi para investor dan pemegang saham adalah masih melemahnya pertumbuhan ekonomi Indonesia bila dilihat dalam lima tahun terakhir sejak 2014. Disisi lain tujuan utama dalam sebuah perusahaan didirikan salah satunya untuk memperoleh laba yang optimal. Laba bukan hanya menjadi tolak ukur efektivitas kinerja perusahaan, tetapi laba juga penting untuk menjaga kelangsungan hidup perusahaan. Penyajian laporan keuangan yang diaudit oleh lembaga akuntan publik yang terpercaya merupakan gambaran dari suatu perusahaan dari segi keuangan pada waktu tertentu yang menunjukkan kondisi keuangan perusahaan yang telah dicapai perusahaan dalam periode tertentu. Laporan keuangan merupakan ringkasan dari suatu proses pencatatan yang isinya merupakan suatu ringkasan dari transaksi-transaksi keuangan yang terjadi selama tahun buku yang bersangkutan. Kinerja keuangan suatu perusahaan dapat diukur dan dilihat melalui laporan keuangan dengan cara menganalisis laporan keuangan. Harahap (2014:25) mengatakan bahwa kegiatan analisis laporan keuangan merupakan salah satu media untuk mendapatkan informasi yang lebih banyak, lebih baik, akurat, dan dijadikan sebagai bahan dalam proses pengambilan keputusan.

\section{KAJIAN PUSTAKA}

Laporan keuangan merupakan gambaran secara ringkas mengenai aktivitas perusahaan dalam pengelolaan keuangan dalam satu tahun. Laporan keuangan ini diberikan secara periodik oleh perusahaan dan disajikan secara tertulis dan diaudit oleh lembaga akuntan publik yang ditunjuk oleh perusahaan yang memberikan informasi secara kuantitatif tentang bagaimana kondisi posisi keuangan dan perubahan-perubahannya, serta hasil yang dicapai selama periode tahun tertentu. Laporan keuangan disusun memiliki tujuan untuk menyediakan informasi keuangan mengenai suatu perusahaan kepada pihakpihak yang berkepentingan seperti para investor dan pemegang saham sebagai pertimbangan dalam pembuatan keputusan langkah strategis perusahaan kedepan. Laporan keuangan adalah laporan yang disajikan untuk kepentingan para pembuat keputusan, terutama pihak di luar perusahaan, mengenai posisi keuangan dan hasil usaha perusahaan, 
Soemarso (2016:34). Sedangkan menurut Harahap (2014:190), analisis laporan keuangan berarti menguraikan pos-pos laporan keuangan menjadi unit informasi yang lebih kecil dan melihat hubungannya yang bersifat signifikan atau yang mempunyai makna antara satu dengan yang lain baik antara data kuantitatif maupun data non-kuantitatif dengan tujuan untuk mengetahui kondisi keuangan lebih dalam yang sangat penting dalam proses menghasilkan keputusan yang tepat. Menurut Prastowo (2015:15-20) bentuk laporan keuangan keuangan yang disajikan oleh perusahaan dalam setiap periode tahun pelaporan terdiri dari gambaran kondisi tentang:

1. Neraca yang berisi tentang laporan keuangan yang memeberikan gambaran informasi mengenai posisi keuangan perusahaan pada tahun tertentu yang terdiri dari aktiva, kewajiban, dan ekuitas.

2. Laba rugi tentang informasi laporan keuangan yang memberikan informasi tentang bagaimana kemampuan serta potensi hambatan perusahaan dalam menghasilkan laba selama periode tahun tertentu.

3. Laporan perubahan ekuitas merupakan laporan keuangan yang menunjukkan nilai perubahan keuangan tentang ekuitas selama satu tahun periode.

4. Laporan arus kas yang memberikan informasi tentang aliran kas masuk dan kas keluar bagi aktivitas operasi, investasi, dan keuangan perusahaan secara terpisah selama satu periode tahun tertentu.

5. Catatan atas laporan keuangan informasi dan analisa atas laporan keuangan perusahaan yang diberikan berkaitan dengan laporan keuangan yang disajikan.

Analisis rasio keuangan dipakai sebagai sistem peringatan awal bagi para pihak yang berkepentingan terhadap kinerja perusahaan yang berisikan informasi terhadap bagaimana kemajuan serta kemunduran kondisi keuangan dari suatu perusahaan. Analisis rasio dapat membimbing investor membuat keputusan atau pertimbangan tentang apa yang akan dicapai oleh perusahaan dan atau bagaimana prospek yang akan dihadapi dimasa yang akan datang. Menurut James C van Horne dalam buku Kasmir (2015:104) analisis rasio keuangan adalah indeks yang menghubungkan dua angka akuntansi dan diperoleh dengan membagi satu angka dengan angka lainnya.

\section{Rasio Solvabilitas}

Rasio solvabilitas merupakan rasio yang digunkan untuk mengukur sejauh mana aktiva perusahaan dibiayai dari hutang. Artinya berapa besar beban utang yang ditanggung 
perusahaan dibandingkan dengan aktivanya. Dalam arti luas dikatakan bahwa rasio ini digunkan untuk mengukur kemampuan perusahaan untukmembayar seluruh kewajibannya, baik jangka pendek maupun jangka panjang apabila perusahaan dibubarkan (dilikuidasi). Semakin tinggi rasio solvabilitas maka semakin tinggi pula resiko kerugian yang dihadapi, tetapi juga ada kesempatan mendapatkan laba yang besar. Sebaliknya apabila perusahaan memiliki rasio solvabilitas yang rendah tentu mempunyai resiko kerugian yang lebih kecil. Adapun jenis rasio solvabilitas yang sering digunkan perusahaan :

1. Debt to asset ratio (DAR)

Rasio ini merupakan rasio utang yang digunakan untuk mengukur perbandingan antara total utang dengan total aktiva. Dengan kata lain, seberapa besar aktiva perusahaan dibiayai oleh utang atau seberapa besar utang perusahaan berpengaruh terhadap pengelolaan aktiva. Rumus DAR $=$ Total Utang/total aset $\mathrm{x} 100$

2. Debt to equity ratio (DER)

Rasio ini merupakan rasio yang digunakan untuk menilai utang dengan ekuitas. Rasio ini dicari dengan cara membandingkan antara seluruh utang termasuk utang lancar dengan seluruh ekuitas. Rasio ini berguna untuk mengetahui jumlah dana yang disediakan pinjaman (kreditor) dengan pemilik preusan. Dengan kata lain rasio ini berfungsi untuk mengetahui setiap rupiah modal sendiri yang dijadikan untuk jaminan utang. Rumus DER $=$ Total Utang/Ekuitas x 100

3. Times interest earned ratio (TIER)

Rasio ini merupakan rasio untuk mencari jumlah kali perolehan bunga. Rasio ini untuk mencari jumlah kali perolehan bunga. Rasio ini juga diartikan sebagai alat ukur untuk mengukur kemampuan perusahaan untuk membayar biaya bunga, sama seperti coverage ratio. Semakin tinggi rasio ini maka semakin besar kemungkinan perusahaan dapat bunga pinjaman dan dapat menjadi ukuran untuk memperoleh tambahan pinjaman baru dari kreditor. Demikian pula sebaliknya apabila rasionya rendah semakin rendah pula kemampuan perusahaan untuk membayar bunga dan biaya lainnya. Rumus TIER = EBIT/Biaya bunga

\section{Rasio Aktivitas}

Rasio ini merupakan rasio yang digunakan untuk mengukur efektifitas perusahaan dalam menggunakan aktiva yang dimilikinya.atau dapat pula dikatakan rasio ini digunakan untuk mengukur tingkat efisiensi (efektifitas) pemanfaatan sumber daya perusahaan. 
Menurut Fahmi (2012:177), rasio aktivitas pengukuran kinerja sebuah perusahaan dalam mengambarkan sejauh mana suatu perusahaan mempergunakan sumber daya yang dimiliki guna menunjang aktivitas perusahaan. Lebih lanjut menurut Fahmi (2012:77) Rasio Aktivitas terdiri dari

1. Perputaran Persediaan (Inventory Turnover)

Perputaran persediaan merupakan rasio yang digunakan untuk mengukur berapa kali dana yang ditanam dalam persediaan ini berputar dalam satu periode. Rasio ini dikenal dengan nama rasio perputaran persediaan. Semakin tinggi rasio ini maka hal ini menunjukkan perusahaan bekerja semakin efisien dan likuid persediaan semakin baik. Rumus Inventory Turnover $=$ Harga Pokok Penjualan/Persediaan

2. Perputaran Total Aset (Total Assets Turnover)

Merupakan rasio yang digunakan untuk mengukur berapa kali dana yang ditanamkan dalam aktiva tetap berputar dalam satu periode. Dengan kata lain rasio ini untuk mengukur apakah perusahaan sudah menggunakan kapasitas aktiva tetap sepenuhnya atau belum. Rumus Total Assets Turnover $=$ Penjualan/Total Asset

3. Perputaran Piutang (Receivable Turnover)

Rasio ini merupakan rasio yang digunakan untuk mengukur berapa lama penagihan piutang selama satu periode atau berapa kali dana yang ditanam dalam piutang ini berputar dalam satu periode. Rumus Receivable Turnover $=$ Total penjualan/total utang

\section{Rasio Profitabilitas}

Rasio ini digunakan untuk mengukur seberapa besar kemampuan perusahaan dalam menghasilkan keuntungan pada tingkat penjualan, asset, dan modal saham tertentu, Hanafi dan Halim (2012:81-82). Dalam rasio profitabilitas antara lain:

1. Net Profit Margin adalah rasio yang digunakan untuk menghitung sejauh mana kemampuan perusahaan dalam menghasilkan laba bersih pada tingkat penjualan tertentu.

Rumus Net Profit Margin = Laba bersih/Penjualan $\mathrm{x} 100 \%$

2. Return On Asset adalah rasio yang digunakan untuk mengukur kemampuan perusahaan dalam menghasilkan laba bersih berdasarkan tingkat aset tertentu.

Rumus Return On Asset = Laba bersih/Total aset x 100\%

3. Return On Equity adalah rasio yang digunakan untuk mengukur kemampuan 
perusahaan dalam menghasilkan laba bersih berdasarkan modal saham tertentu.

Rumus Return On Equity= Laba bersih/Modal x100\%

\section{Penelitian Terdahulu}

Beberapa penelitian terdahulu sudah banyak dilakukan dalam mengukur bagaimana kinerja sebuah perusahaan dapat dilakukan mengunakan analisis rasio keuangan diantaranya adalah rasio profitabilitas dan rasio likuiditas. Berikut data penelitian terdahulu

Tabel 1. Penelitian Terdahulu

\begin{tabular}{|c|c|c|c|}
\hline No & Penulis & Judul Penelitian & Hasil \\
\hline 1 & $\begin{array}{l}\text { Sulastri, } \\
\text { Hapsari(2015) }\end{array}$ & $\begin{array}{l}\text { Analisis kinerja } \\
\text { perusahan jika dilihat } \\
\text { dari rasio } \\
\text { likuiditasi,solvabilitas } \\
\text { dan profitabilitas ( PT. } \\
\text { Andalan Finance } \\
\text { Indonesia Semarang) }\end{array}$ & $\begin{array}{l}\text { Rasio likuiditas dilihat dari Current Ratio tahun } \\
2011 \text { lebih baik dibanding tahun } 2012 \text { dan tahun } \\
2013 \text {. }\end{array}$ \\
\hline 2 & Tanor et al. (2015) & $\begin{array}{l}\text { Rasio likuiditas, } \\
\text { solvabilitas dan } \\
\text { profitabilitas untuk } \\
\text { mengukur kinerja } \\
\text { keuangan perusahaan } \\
\text { Bank Artha Graha } \\
\text { dalam memenuhi } \\
\text { kewajiban jangka } \\
\text { pendek yang dimiliki. }\end{array}$ & $\begin{array}{l}\text { Hasil solvabilitas memperlihatkan kemampuan } \\
\text { bank dalam permodalan yang dimiliki mampu } \\
\text { untuk menutupi penurunan maupun kerugian. } \\
\text { Hasil profitabilitas memperlihatkan bank } \\
\text { memiliki hasil rasio yang terus meningkat. } \\
\text { Kondisi keuangan Bank Artha Graha masih } \\
\text { dalam keadaan baik dan dapat memenuhi } \\
\text { kewajiban terhadap pihak ketiga. }\end{array}$ \\
\hline 3 & Yaqin (2014) & $\begin{array}{l}\text { Analisis Rasio } \\
\text { Keuangan Untuk } \\
\text { Menilai Kinerja } \\
\text { Keuangan Pada } \\
\text { Perusahaan Semen } \\
\text { Tbk. }\end{array}$ & $\begin{array}{l}\text { Hasil analisis menunjukkan bahwa tingkat rasio } \\
\text { dari likuiditas, solvabilitas, profitabilitas, dan } \\
\text { aktivitas bahwa kinerja keuangan rata-rata } \\
\text { kurang baik, jadi perlu ditingkatkan dengan } \\
\text { memanfaatkan modal yang ada. }\end{array}$ \\
\hline 4 & Aristyanti (2014) & $\begin{array}{l}\text { Analisis Kinerja } \\
\text { Keuangan Perusahaan } \\
\text { Ditinjau dari } \\
\text { Profitabilitas dan } \\
\text { Likuiditas Pada PT. } \\
\text { H.M. Sampoerna, Tbk. }\end{array}$ & $\begin{array}{l}\text { Hasil penelitian menunjukkan rasio likuiditas } \\
\text { mengalami penurunan yang disebabkan } \\
\text { terjadinya aktiva lancar lebih rendah daripada } \\
\text { hutang lancarnya. }\end{array}$ \\
\hline & & & \\
\hline
\end{tabular}

\section{METODE PENELITIAN}

Metode penelitian yang penulis digunakan adalah kualitatif deskriptif dimana metode ini untuk mengetahui kinerja perusahaan dari sisi keuangan pada periode tahun 2014-209 PT. Bukit Asam. Penelitian ini dilakukan pada perusahaan yang terdaftar di 
Bursa Efek Indonesia. Dalam penulisan ini penulis melakukan pengumpulan data yang digunakan untuk penelitian ini dengan cara melakukan pengambilan dokumentasi laporan keuangan perusahaan dari tahun 2014-2019. Penulis pada metode analisis data yang digunakan dalam penelitian ini adalah metode analisis deskriptif, dimana metode dilakukan dengan cara mengumpulkan, menyajikan, serta menganalisis data sehingga diperoleh gambaran yang jelas tentang peluang, rencana serta hambatan masalah yang dihadapi oleh PT. Bukit Asam, lalu disajikan dalam bentuk kesimpulan sesuai keadaan kondisi perusahaan saat ini.

\section{ANALISIS DAN PEMBAHASAN}

\section{Sekilas PT. Bukit Asam}

Pemerintah Indonesia pada tahun 1950, mengesahkan pembentukan perusahaan negara tambang arang Bukit Asam (PN TABA). Pada tanggal 1 Maret 1981, PN TABA kemudian berubah status menjadi perseroan terbatas dengan nama PT Bukit Asam (Persero). Dalam rangka meningkatkan pengembangan industri batu bara di Indonesia, pada 1990 Pemerintah menetapkan penggabungan perum tambang batubara dengan perseroan. Sesuai dengan program pengembangan ketahanan energi nasional, pada 1993 pemerintah menugaskan perseroan untuk mengembangkan usaha briket batu bara. Pada 23 Desember 2002, Perseroan mencatatkan diri sebagai perusahaan publik di Bursa Efek Indonesia dengan kode perdagangan "PTBA". Pada tanggal 29 November 2017, menjadi catatan sejarah bagi PTBA saat menyelenggarakan rapat umum pemegang saham luar biasa dengan agenda utama RUPSLB PTBA mencakup tiga hal, yakni persetujuan perubahan anggaran dasar perseroan terkait perubahan status perseroan dari persero menjadi nonpersero sehubungan dengan PP 47/2107 tentang penambahan penyertaan modal. http://www.ptba.co.id/id/tentang-kami/profil-perusahaan.

\section{Rasio solvabilitas}

Rasio solvabilitas merupakan rasio yang digunkan untuk mengukur sejauh mana aktiva perusahaan dibiayai dari hutang. Artinya berapa besar beban utang yang ditanggung perusahaan dibandingkan dengan aktivanya

\section{Debt to asset ratio (DAR)}

Rasio ini merupakan rasio utang yang digunakan untuk mengukur perbandingan 
antara total utang dengan total aktiva. Rumus DAR $=$ Total Utang/total aset $\mathrm{x} 100$

Tabel 2. Perhitungan Debt to asset ratio

(Dalam jutaan rupiah)

\begin{tabular}{|l|c|c|c|c|c|c|}
\hline \multicolumn{1}{|c|}{ Keterangan } & 2014 & 2015 & 2016 & 2017 & 2018 & 2019 \\
\hline Total Utang & 6.141 .181 & 7.606 .496 & 10.759 .690 & 12.120 .536 & 7.903 .237 & 7.675 .226 \\
Total Aset & 14.812 .023 & $\begin{array}{c}16.894 .04 \\
3\end{array}$ & 18.576 .774 & 21.987 .482 & 24.172 .933 & 26.098 .052 \\
\hline DAR & 0,42 & 0,45 & 0,58 & 0,55 & 0,33 & 0,29 \\
\hline Rata-rata DAR & \multicolumn{7}{|c|}{0,43} & \\
\hline
\end{tabular}

Sumber : data sekunder diolah, 2020

Berdasarkan hasil perhitungan pada tabel 2. menunjukan bahwa DAR PT. Bukit Asam pada tahun 2016 mencapai nilai paling tinggi sebesar 0,58 bila dibandingkan oleh tahun lainnya, dimana aset perusahaan sebanyak 0,58 atau 58\% di biayai oleh hutang perusahaan dan sisanya 0,42 atau $42 \%$ di biayai oleh aset perusahaan, sedangkan nilai terendah 0,29 terjadi pada tahun 2019, dimana aset perusahaan sebanyak 0,29 atau $29 \%$ dibiayai oleh hutang dan sisanya $71 \%$ di biayai oleh aset perusahaan. Nilai rata-rata DAR dari tahun 2014-2014 sebesar 0,43 atau 43\%. Kesimpulannya adalah semakain rendah nilai DAR, maka semakin kecil juga aset perusahaan yang dibiayai oleh hutang perusahaan.

\section{B. Debt to equity ratio (DER)}

Rasio ini merupakan rasio yang digunakan untuk menilai utang dengan ekuitas dari sebuah perusahaan. Rumus DER = Total Utang/Ekuitas x 100

Tabel 3. Perhitungan Debt to equity ratio (DER)

(Dalam jutaan rupiah)

\begin{tabular}{|l|c|c|c|c|c|c|}
\hline \multicolumn{1}{|c|}{ Keterangan } & 2014 & 2015 & 2016 & 2017 & 2018 & 2019 \\
\hline Total Utang & 6.141 .181 & 7.606 .496 & 10.759 .690 & 12.120 .536 & 7.903 .237 & 7.675 .226 \\
& & & & & & \\
Modal & 8.670 .842 & 9.287 .547 & 10.552 .405 & 13.799 .985 & 16.269 .696 & 18.422 .826 \\
\hline
\end{tabular}




\begin{tabular}{|l|l|l|l|l|l|l|}
\hline DER & 0,71 & 0,82 & 1,02 & 0,88 & 0,49 & 0,42 \\
\hline Rata-rata DER & \multicolumn{8}{|c|}{0,72} \\
\hline
\end{tabular}

\section{Sumber : data sekunder diolah, 2020}

Berdasarkan hasil perhitungan pada tabel 3. Menunjukan nilai debt to equity ratio terendah terjadi pada tahun 2019 sebesar 0,42 atau 42\% dan tertinggi pada tahun 2016 sebesar 1,02 atau 102\%, sedangkan nilai rata-rata debt equity ratio selama enam tahun sebesar 0,72 atau $72 \%$. Analisa dari perhitungan nilai DER ini ialah kreditor menyediakan Rp. 42,- pada tahun 2019 untuk setiap Rp.100,- yang disediakan pemegang saham pada tahun dimana nilai DER paling rendah sehingga PT. Bukit Asam dibiayai oleh utang sebanyak 42\%. Sedangkan pada tahun 2016 dimana nilai DER paling tinggi kreditor menyediakan Rp 102 untuk setiap Rp 100 yang disediakan pemegang saham.Kesimpulan dari dario ini adalah Semakin kecil nilai rasio DER PT. Bukit Asam maka kinerja perusahaan semakin baik dimana operasional perusahaan tidak terlalu besar dibiayai oleh hutang.

\section{Times interest earned ratio (TIER)}

Rasio ini merupakan rasio untuk mencari jumlah kali perolehan bunga. Rasio ini untuk mencari jumlah kali perolehan bunga. Rumus TIER = EBIT/Biaya bunga

Tabel 4. Perhitungan Times interest earned ratio (TIER)

(Dalam jutaan rupiah)

\begin{tabular}{|l|c|c|c|c|c|c|}
\hline Keterangan & 2014 & 2015 & 2016 & 2017 & 2018 & 2019 \\
\hline EBIT & 4.021 .743 & 2.663 .796 & 4.401 .469 & 8.506 .506 & 8.545 .793 & 7.611 .504 \\
Bunga & 38.708 & 50.595 & 25.795 & 83.910 & 94.650 & 75.640 \\
\hline TIER & 103,9 & 52,6 & 170,6 & 101,4 & 90,3 & 100,6 \\
\hline Rata-rata TIER & \multicolumn{70}{|c|}{103,2} \\
\hline
\end{tabular}

\section{Sumber : data sekunder diolah, 2020}

Berdasarkan hasil perhittungan pada tabel 4, menunjukan hasil TEIR tertinggi terjadi pada tahun 2016 sebesar 170,6 dan terendah pada tahun 2015 sebesar 52,6, sedangkan nilai rata-rata TIER PT. Bukit Asam selam enam tahun sebesar 103,2. Jika dilihat dari perhitungan ini maka times interest earned terendah tahun 2015 adalah 52 kali atau dengan kata lain, biaya bunga dapat ditutup 52 kali sehingga, biaya bunga dapat ditutup 52 kali dari laba sebelum bunga dan pajak. Tetapi untuk tahun 2017 sebesar 170,6 
kali dengan kata lain biaya bunga dapat ditutup 170,6 kali laba sebelum bunga dan pajak. Semakin tinggi nilai TIER maka akan menyulitkan perusahaan untuk mendapatkan pinjaman dari perbankan dan menurunkan kinerja perusahaan.

\section{Rasio Aktivitas}

Rasio ini merupakan rasio yang digunakan untuk mengukur efektifitas perusahaan dalam menggunakan aktiva yang dimilikinya.

\section{Perputaran Persediaan (Inventory Turnover)}

Perputaran persediaan merupakan rasio yang digunakan untuk mengukur berapa kali dana yang ditanam dalam persediaan ini berputar dalam satu periode. Rumus Inventory Turnover $=$ Harga Pokok Penjualan/Persediaan

Tabel 5. Perhitungan Perputaran Persediaan (Inventory Turnover)

(Dalam jutaan rupiah)

\begin{tabular}{|l|c|c|c|c|c|c|}
\hline Keterangan & 2014 & 2015 & 2016 & 2017 & 2018 & 2019 \\
\hline HPP & 9.056 .219 & 9.593 .903 & 9.657 .400 & 10.964 .524 & 12.621 .200 & 14.176 .060 \\
Persediaan & 1.033 .360 & 1.233 .175 & 1.102 .290 & 1.156 .012 & 1.551 .135 & 1.383 .064 \\
\hline $\begin{array}{l}\text { Inventory } \\
\text { Turnover }\end{array}$ & 8,76 & 7,78 & 8,76 & 9,48 & 8,14 & 10,25 \\
\hline Rata-rata IT & \multicolumn{7}{|c|}{8,86} & \\
\hline
\end{tabular}

Sumber : data sekunder diolah, 2020

Berdasarkan hasil perhitungan pada tabel 5, menunjukan hasil Inventory turnover tertinggi terjadi pada tahun 2019 sebesar 10,25 dan terendah pada tahun 2015 sebesar 7,78 sedangkan nilai rata-rata Inventory turnover PT. Bukit Asam selam enam tahun sebesar 8,86. Analisa ini menunjukan bahwa pada tahun tertinggi 2019 menunjukkan 10,25 kali persediaan barang dagangan diganti dalam satu tahun. Sedangkan tahun 2015 nenunjukan 7,78 kali persediaan barang dagangan diganti dalam satu tahun. Hal ini menunjukan bahwa jika dihitung rata-rata Inventory turnover 8,86, artinya kinerja dari sisi Inventory turnover perusahan masih belum baik karena masih lebih banyak menahan persediaan.

\section{Perputaran Total Aset (Total Assets Turnover)}

Merupakan rasio yang digunakan untuk mengukur berapa kali dana yang 
ditanamkan dalam aktiva tetap berputar dalam satu periode. Rumus Total Assets Turnover $=$ Penjualan/Total Asset

Tabel 6. Perhitungan Perputaran Total Aset (Total Assets Turnover)

(Dalam jutaan rupiah)

\begin{tabular}{|l|c|c|c|c|c|c|}
\hline Keterangan & 2014 & 2015 & 2016 & 2017 & 2018 & 2019 \\
\hline Penjualan & 13.077 .962 & 13.733 .627 & 14.058 .869 & 19.471 .030 & 21.166 .993 & 21.787 .564 \\
Total Aset & 14.812 .023 & 16.894 .043 & 18.576 .774 & 21.987 .482 & 24.172 .933 & 26.098 .052 \\
\hline $\begin{array}{l}\text { Total Assets } \\
\text { Turnover }\end{array}$ & 0.88 & 0.81 & 0.76 & 0.89 & 0.88 & 0.83 \\
\hline Rata-rata TAT & \multicolumn{7}{|c|}{0.84} \\
\hline
\end{tabular}

Sumber : data sekunder diolah, 2020

Berdasarkan hasil perhitungan pada tabel 6 , menunjukan hasil total asset turnover tertinggi terjadi pada tahun 2017 sebesar 0.89 dan terendah pada tahun 2016 sebesar 0.76 sedangkan nilai rata-rata Inventory turnover PT. Bukit Asam selam enam tahun sebesar 0.84. Analisa perhitungan menunjukan bahwa pada tahun tertinggi 2017 kemampuan dana yang tertanam dalam persediaan berputar dalam suatu periode tertentu. Setiap Rp. 1 aset mampu menghasilkan penjualan bersih sebesar Rp. 0.89. Sedangkan pada tahun terendah 2016 kemampuan dana yang tertanam dalam persediaan berputar dalam suatu periode tertentu. Setiap Rp. 1 aset mampu menghasilkan penjualan bersih sebesar Rp. 0,76.

\section{Perputaran Piutang (Receivable Turnover)}

Rasio ini merupakan rasio yang digunakan untuk mengukur berapa lama penagihan piutang selama satu periode. Rumus Receivable Turnover $=$ Total penjualan/total utang

Tabel 7. Perhitungan Perputaran Piutang (Receivable Turnover)

(Dalam jutaan rupiah)

\begin{tabular}{|l|c|c|c|c|c|c|}
\hline Keterangan & 2014 & 2015 & 2016 & 2017 & 2018 & 2019 \\
\hline Penjualan & 13.077 .962 & 13.733 .627 & 14.058 .869 & 19.471 .030 & 21.166 .993 & 21.787 .564 \\
\hline
\end{tabular}




\begin{tabular}{|l|c|c|c|c|c|c|} 
Piutang & 1.468 .682 & 1.638 .707 & 2.328 .448 & 5.389 .678 & 2.834 .411 & 2.777 .691 \\
\hline $\begin{array}{l}\text { Receivable } \\
\text { Turnover }\end{array}$ & 8,90 & 8,38 & 6,04 & 3,61 & 7,47 & 7,84 \\
\hline Rata-rata RT & \multicolumn{7}{|c|}{7,04} \\
\hline
\end{tabular}

Sumber : data sekunder diolah, 2020

Berdasarkan data perhitungan pada tabel 7 dapat dilihat perhitungan bahwa receivable turnover hasil PT. Bukit Asam, Tbk pada tahun 2014-2019. secara keseluruhan hasil paling tinggi terdapat pada tahun 2014 sebesar 8,90 dan terendah tahun 2017 sebesar 3,61, sedangkan nilai rata-rata receivable turnover PT. Bukit Asam selam enam tahun sebesar 7,04. Hasil ini menunjukan bahwa perputaran piutang untuk tahun tertinggi 2014 sebesar 8,90 kali, sedangkan untuk tahun terendah 2017 sebesar 3,61 kali dibandingkan penjualan. Kesimpulannya semakin tinggi nilai rasio maka perusahan dapat dinilai baik dalam melakukan penagihan piutang dan sebaliknya.

\section{Rasio Profitabilitas}

Rasio profitabilitas digunakan sebagai alat untuk mengukur kapasitas pendapatan perusahaan yang dapat dijadikan sebagai indikator untuk melihat seberapa besar pertumbuhan, keberhasilan, dan sebagai alat kontrol bagi perusahaan dalam menhadapi perubahan kebijakan yang ditentukan. Rasio ini juga menunjukkan kemajuan dan tingkat pengembalian atas investasi yang dilakukan oleh investor.

\section{Net Profit Margin}

Net profit margin adalah rasio yang digunakan untuk mengukur margin laba atas penjualan. Berikut tabel data perhitungan net profit margin PT. Bukit Asam tahun 20142019. Rumus Net Profit Margin = Laba bersih/Penjualan $\times 100 \%$

Tabel 8. Perhittungan Rasio Net Profit Margin.

(Dalam jutaan rupiah)

\begin{tabular}{|l|c|c|c|c|c|c|}
\hline \multicolumn{1}{|c|}{ Keterangan } & 2014 & 2015 & 2016 & 2017 & 2018 & 2019 \\
\hline $\begin{array}{l}\text { Laba Setelah } \\
\text { Pajak }\end{array}$ & 4.021 .743 & 2.663 .796 & 4.401 .796 & 8.506 .506 & 8.545 .793 & 7.611 .504 \\
Penjualan & $\begin{array}{c}13.077 .96 \\
2\end{array}$ & 13.733 .627 & 14.058 .869 & 19.471 .030 & 21.166 .993 & 21.787 .564 \\
\hline
\end{tabular}




\begin{tabular}{|l|c|c|c|c|c|c|}
\hline $\begin{array}{l}\text { Net Profit } \\
\text { Margin (\%) }\end{array}$ & $30.75 \%$ & $19.40 \%$ & $31.31 \%$ & $43.69 \%$ & $40.37 \%$ & $34.94 \%$ \\
\hline Rata-rata NPM & \multicolumn{7}{|c|}{$33.41 \%$} \\
\hline
\end{tabular}

\section{Sumber : data sekunder diolah, 2020}

Berdasarkan data perhitungan pada tabel 8 dapat dilihat bahwa hasil perhitungan net profit margin PT. Bukit Asam,Tbk pada tahun 2014-2019. Besarnya net profit margin yang dihasilkan pada tahun 2014-2019 secara keseluruhan hasil tertinggi tahun 2017 sebesar 43,69\% dan terendah tahun 2015 sebesar 19,40\%. Penurunan nilai dari tahun 20172019, dimana pada tahun 2017 net profit margin sebesar 43,69\% dan menurun pada tahun 2018 dan 2019 masing-masing 40,37\% dan 34,94\%. Hal ini menunjukkan bahwa perusahaan tidak mampu mendapatkan hasil (laba) yang baik melalui penjualan sehingga melebihi beban pokok penjualan yang dikeluarkan oleh perusahaan.

\section{B. Return On Asset}

Return On Asset adalah rasio yang digunakan untuk mengukur kemampuan perusahaan dalam menghasilkan laba bersih berdasarkan tingkat aset tertentu. Rumus Return On Asset = Laba bersih/Total aset x 100\%

\section{Tabel 9. Perhitungan Return On Asset}

(Dalam jutaan rupiah)

\begin{tabular}{|l|c|c|c|c|c|c|}
\hline \multicolumn{1}{|c|}{ Keterangan } & 2014 & 2015 & 2016 & 2017 & 2018 & 2019 \\
\hline Laba Bersih & 2.019 .214 & 2.037 .111 & 2.024 .111 & 4.542 .232 & 5.121 .112 & 4.040 .394 \\
Total Aset & 14.812 .023 & 16.894 .043 & 18.576 .774 & 21.987 .482 & 24.172 .933 & 26.098 .052 \\
\hline ROA (\%) & $13,63 \%$ & $12,06 \%$ & $10,90 \%$ & $20,66 \%$ & $21,19 \%$ & $15,48 \%$ \\
\hline Rata-rata ROA(\%) & \multicolumn{7}{|c|}{$15,65 \%$} \\
\hline
\end{tabular}

\section{Sumber : data sekunder diolah, 2020}

Berdasarkan data perhitungan pada tabel 9 dapat dilihat perhitungan bahwa hasil return on asset PT. Bukit Asam, Tbk pada tahun 2014-2019. Nilai return on asset yang dihasilkan pada tahun 2014-2019 secara keseluruhan hasil paling tinggi terdapat pada tahun 2018 sebesar 21,19\% dan terendah tahun 2016 sebesar 10,90\%. Peningkatan yang terjadi pada tahun 2017-2018 dari 20,66\% menjadi 21,19\%. Hal ini menunjukkan bahwa kemampuan perusahaan dalam menghasilkan laba bersih berdasarkan aktiva yang dimiliki cukup baik. Sehingga aktiva yang dimiliki dapat lebih cepat berputar untuk mendapatkan 
laba. Dengan demikian dapat diketahui bahwa pada tahun 2014-2019 rata-rata return on asset yang dihasilkan PT. Bukit Asam, Tbk sebesar 15,65\%. Hasil tersebut menunjukkan bahwa bahwa rata-rata return on asset yang dihasilkan semakin baik bagi perusahaan dan return on asset yang tinggi menunjukkan efisiensi perusahaan dalam melaksanakan operasi sehari-hari.

\section{Return On Equity}

Return On Equity adalah rasio yang digunakan untuk mengukur kemampuan perusahaan dalam menghasilkan laba bersih berdasarkan modal saham tertentu. Rumus Return On Equity= Laba bersih/Modal $\mathrm{x} 100 \%$

Tabel 10. Perhitungan Return On Equity

(Dalam jutaan rupiah)

\begin{tabular}{|l|c|c|c|c|c|c|}
\hline \multicolumn{1}{|c|}{ Keterangan } & 2014 & 2015 & 2016 & 2017 & 2018 & 2019 \\
\hline Laba Bersih & 2.019 .214 & 2.037 .111 & 2.024 .405 & 4.542 .232 & 5.121 .112 & 4.040 .394 \\
Modal & 8.670 .842 & 9.287 .547 & 10.552 .405 & 13.799 .985 & 16.269 .696 & 18.422 .826 \\
\hline ROE (\%) & $23,29 \%$ & $21,93 \%$ & $19,18 \%$ & $32,91 \%$ & $31,48 \%$ & $21,93 \%$ \\
\hline Rata-rata ROE $(\%)$ & \multicolumn{7}{|c|}{$25,12 \%$} \\
\hline
\end{tabular}

Sumber : data sekunder diolah, 2020

Berdasarkan data perhitungan pada tabel 10. dapat disimpulkan perhitungan return on equity PT. Bukit Asam, Tbk pada tahun 2014-2019. Bahwa besarnya return on equity yang dihasilkan pada tahun 2014-2019 secara keseluruhan pada hasil pada tahun 2017 tertinggi sebesar 32,91\% dan terendah tahun 2016 sebesar 19,18\%. Sedangkan angka peningkatan terjadi pada tahun 2016-2017 dari 19,18\% menjadi 32,91\%. Angka rata-rata rasio ROE dari tahun 2014-2019 sebesar 25,12\%. Sehingga semakin tinggi return on equity yang diperoleh maka kinerja perusahaan akan semakin baik. Artinya posisi pemilik perusahaan semakin kuat, hanya saja peningkatan tersebut masih kurang efisien jika dinilai dengan penggunaan modal sendiri yang telah dimiliki perusahaan.

Tabel 11. Rasio keungan PT. Bukit Asam, Tbk

Periode 2014-2019

\begin{tabular}{|l|c|c|c|c|c|c|}
\hline Rasio & 2014 & 2015 & 2016 & 2017 & 2018 & 2019 \\
\hline Debt to asset ratio & $41 \%$ & $45 \%$ & $58 \%$ & $55 \%$ & $33 \%$ & $29 \%$ \\
\cline { 2 - 7 }
\end{tabular}




\begin{tabular}{|l|c|c|c|c|c|c|}
\cline { 2 - 7 } $\begin{array}{l}\text { Debt to equity ratio } \\
\text { Times interest earned ratio }\end{array}$ & $71 \%$ & $82 \%$ & $102 \%$ & $88 \%$ & $49 \%$ & $42 \%$ \\
\cline { 2 - 7 } $\begin{array}{l}\text { Inventory Turnover } \\
\text { Total Assets Turnover }\end{array}$ & 103,9 & 52,6 & 170,6 & 101,4 & 90,3 & 100,6 \\
\cline { 2 - 7 } Receivable Turnover & 8,76 & 7,78 & 8,76 & 9,48 & 8,14 & 10,25 \\
\cline { 2 - 7 } & 0.88 & 0.81 & 0.76 & 0.89 & 0.88 & 0.83 \\
\cline { 2 - 7 } Net Profit Margin & 8,90 & 8,38 & 6,04 & 3,61 & 7,47 & 7,84 \\
\cline { 2 - 7 } & $30.75 \%$ & $19.40 \%$ & $\begin{array}{c}31.31 \\
\%\end{array}$ & $43.69 \%$ & $40.37 \%$ & $34.94 \%$ \\
\hline \multirow{2}{*}{ Return On Asset } & $13,63 \%$ & $12,06 \%$ & $\begin{array}{c}10,90 \\
\%\end{array}$ & $20,66 \%$ & $21,19 \%$ & $15,48 \%$ \\
\cline { 2 - 7 } & $23,29 \%$ & $21,93 \%$ & $\begin{array}{c}19,18 \\
\%\end{array}$ & $32,91 \%$ & $31,48 \%$ & $21,93 \%$ \\
\hline
\end{tabular}

Sumber : data sekunder diolah, 2020

\section{KESIMPULAN DAN SARAN}

\section{Kesimpulan}

Kinerja PT. Bukit Asam, Tbk bila dilihat dari rasio profitabilitas yang berfluktuasi dan tidak stabil atas margin laba bersih terutama terjadi angka penurunan pada tahun 2015 sebesar 19,40\% dan tertinggi pada tahun 2017 sebesar 43,69\%, menunjukan bahwa kinerja perusahaan belum bisa menaikan laba bersih perusahaan ditengah dampak pertumbuhan ekonomi Indonesia yang belum tumbuh secara maksimal sesuai target pemerintah memang memberikan dampak yang sangat besar bagi perusahaan. Dari sisi rasio solvabilitas kemampuan membayar liabilitas jangka pendek maupun jangka panjang perusahaan terlihat dari rasio solvabilitas yang terdiri dari rasio liabilitas terhadap ekuitas, atau Debt to Equity Ratio (DER), serta rasio Liabilitas terhadap Aset, atau Debt to Asset Ratio (DAR). Debt to Equity Ratio (DER) perusahaan tahun 2019 sebesar 42\%, mengalami penurunan dibandingkan dengan tahun 2018 sebesar 49\%. Penurunan DER hingga 7\% menunjukkan tingkat ketergantungan perusahaan terhadap pihak luar sebagai sumber keuangan semakin menurun dan kemampuan perusahaan dalam mengelola pinjaman semakin meningkat. Sedangkan rasio utang terhadap aset perusahaan tahun 2019 sebesar 29\%, mengalami penurunan dibandingkan dengan tahun 2018 sebesar 33\%. Nilai tersebut menunjukkan ditengah pertumbuhan ekonomi yang belum sesuai target pemerintah dalam lima tahun terakhir PT. Bukit Asam berhasil dalam menekan liabilitas serta mengoptimalkan aset yang dimiliki dalam kegiatan operasioalnya. Sedangkan dari sisi rasio aktivitas PT. Bukit Asam, Tbk dari tahun 2014 sampai tahun 2019 menunjukkan bahwa kinerja perusahaan 
khususnya rasio perputaran persediaan dan perputaran piutang perusahaan yang berfluktuasi dan tidak stabil namun kenaikan serta penurunannya tidak signifikan. Sehingga kemampuan perusahaan untuk menghasilkan rasio perputaran total aset cukup baik ditengah pertumbuhan ekonomi Indonesia yang belum sesuai target pemerintah. 5.2 Saran

Berdasarkan hasil penelitian dari ketiga rasio PT. Bukit Asam, penulis memberikan saran kepada perusahaan ditengah melambatnya pertumbuhan ekonomi Indonesia sejak tahun 2014-2019 dalam lima tahun terakhir.

1. PT. Bukit Asam harus melakukan penambahan kapasitas produksi, sehingga peluang untuk meningkatkan laba dimasa datang terbuka lebar, selain itu melakukan penghematan serta menekan biaya produksi serta beban operasional perusahaan terhadap pengeluaran biaya pada tiap divisi.

2. PT. Bukit Asam disarankan melakukan penambahan aset dan mengurangi hutang yang ada dengan tambahan modal sendiri sehingga penggunaan dana yang bersumber dari pinjaman harus dibatasi dan memaksimalkan pengelolaan modal dan aset.

3. PT. Bukit Asam harus meningkatkan penjualan agar persediaan yang tersimpan segera terjual dan tidak terjadi penumpukan persediaan, selain itu perusahaan juga harus melakukan inovasi dalam pemilihan bahan baku alternative untuk produksi dan mengurangi aset yang kurang produktif.

\section{DAFTAR PUSTAKA}

Arifin, Primandari, L. A (2015). Analisis laporan keuangan untuk mengukur kinerja keuangan berdasarkan rasio profitabilitas pada PT. Kereta Api Indonesi dan anak perusahaan. Akutansi bisnis \& manajemen (ABM), 22(2), 115-123.

Fitri, G. (2017). Analisa laporan keuangan untuk mengukur kinerja perusahaan ( Studi kasus PT. Adhi Karya (Persero) Tbk. Jurnal akuntansi barelang. 2(1), 24-35.

Fahmi, Irham. (2012). Pengantar manajemen, Alfabeta, Bandung.

Hanafi, Mahmud. (2007). Analisis laporan keuangan. Liberty. Yogyakarta

Harahap, S. S. (2014). Analisis kritis atas laporan keuangan, Edisi 1. Jakarta: PT. Raja grafindo persada.

Hanafi, M. dan A. Halim. (2012). Analisis laporan keuangan, Edisi Keempat. Cetakan 
Kedua. Sekolah tinggi ilmu manajemen YKPN. Yogyakarta

Prastowo. (2015). Analisa laporan keuangan konsep dan aplikasi, Edisi Kedua. Cetakan Kedelapan. UPP AMP YKPN. Yogyakarta

Ramadhan, K. D, Syarfan, L. O. (2016). Analisis laporan keuangan dalam mengukur kinerja perusahan pada PT. Ricky kurniawan kertapersada (Makin Group) Jambi. Jurnal valuta, Jurnal administrasi bisnis, Manajemen dan ekonomi. 2(2), 190-207. 